J. Dairy Sci. 92:571-580

doi:10.3168/jds.2008-1507

(c) American Dairy Science Association, 2009.

\title{
Impact of hyperketonemia in early lactation dairy cows on health and production
}

\author{
T. F. Duffield, ${ }^{\star 1}$ K. D. Lissemore, ${ }^{*}$ B. W. McBride, $†$ and K. E. Leslie* \\ *Department of Population Medicine, Ontario Veterinary College, University of Guelph, Guelph, Ontario, Canada N1G 2W1 \\ †Department of Animal and Poultry Science, University of Guelph, Guelph, Ontario, Canada N1G 2W1
}

\begin{abstract}
Data from 1,010 lactating lactating, predominately component-fed Holstein cattle from 25 predominately tie-stall dairy farms in southwest Ontario were used to identify objective thresholds for defining hyperketonemia in lactating dairy cattle based on negative impacts on cow health, milk production, or both. Serum samples obtained during wk 1 and 2 postpartum and analyzed for $\beta$-hydroxybutyrate (BHBA) concentrations that were used in analysis. Data were time-ordered so that the serum samples were obtained at least $1 \mathrm{~d}$ before the disease or milk recording events. Serum BHBA cutpoints were constructed at $200 \mu \mathrm{mol} / \mathrm{L}$ intervals between 600 and 2,000 $\mu \mathrm{mol} / \mathrm{L}$. Critical cutpoints for the health analysis were determined based on the threshold having the greatest sum of sensitivity and specificity for predicting the disease occurrence. For the production outcomes, models for first test day milk yield, milk fat, and milk protein percentage were constructed including covariates of parity, precalving body condition score, season of calving, test day linear score, and the random effect of herd. Each cutpoint was tested in these models to determine the threshold with the greatest impact and least risk of a type 1 error. Serum BHBA concentrations at or above $1,200 \mu \mathrm{mol} / \mathrm{L}$ in the first week following calving were associated with increased risks of subsequent displaced abomasum [odds ratio (OR) $=2.60]$ and metritis $(\mathrm{OR}=3.35)$, whereas the critical threshold of BHBA in wk 2 postpartum on the risk of abomasal displacement was $\geq 1,800 \mu \mathrm{mol} / \mathrm{L}$ (OR = 6.22 ). The best threshold for predicting subsequent risk of clinical ketosis from serum obtained during wk 1 and wk 2 postpartum was 1,400 $\mu \mathrm{mol} / \mathrm{L}$ of BHBA $(\mathrm{OR}=$ 4.25 and 5.98, respectively). There was no association between clinical mastitis and elevated serum BHBA in wk 1 or 2 postpartum, and there was no association between wh 2 BHBA and risk of metritis. Greater se-
\end{abstract}

Received July 1, 2008.

Accepted September 25, 2008.

${ }^{1}$ Corresponding author: tduffiel@uoguelph.ca rum BHBA measured during the first and second week postcalving were associated with less milk yield, greater milk fat percentage, and less milk protein percentage on the first Dairy Herd Improvement test day of lactation. Impacts on first Dairy Herd Improvement test milk yield began at $\mathrm{BHBA} \geq 1,200 \mu \mathrm{mol} / \mathrm{L}$ for wk 1 samples and $\geq 1,400 \mu \mathrm{mol} / \mathrm{L}$ for wk 2 samples. The greatest impact on yield occurred at $1,400 \mu \mathrm{mol} / \mathrm{L}(-1.88 \mathrm{~kg} / \mathrm{d})$ and $2,000 \mu \mathrm{mol} / \mathrm{L}(-3.3 \mathrm{~kg} / \mathrm{d})$ for sera from the first and second week postcalving, respectively. Hyperketonemia can be defined at 1,400 $\mu \mathrm{mol} / \mathrm{L}$ of BHBA and in the first 2 wk postpartum increases disease risk and results in substantial loss of milk yield in early lactation.

Key words: dairy cow, hyperketonemia, disease, milk production

\section{INTRODUCTION}

The transition of dairy cows through the dry-period, calving, and commencement of lactation is a critical time and is a strong determinant of the health and performance success of the cow through the full lactation. The cow's ability to manage energy intake and demand through this time period is one of the important contributors to success or failure of the lactation. A successful adaptation to both the onset of lactation and the resulting negative energy balance can provide for a healthy and productive lactation, whereas a poor adaptive response can lead to a multitude of problems including clinical disease and impaired milk production. One indicator of a poor adaptive response is elevations in circulating ketone body concentrations (Herdt, 2000). Whereas ketone elevations postcalving are part of a normal adaptive response, excess ketone accumulation is abnormal.

The case definition of subclinical ketosis in dairy cattle is an excess level of circulating ketone bodies in the absence of the clinical signs of ketosis (Andersson, 1988). Beta-hydroxybutyrate is the predominant circulating ketone body in ruminants, but there is a strong correlation between the whole blood concentrations of BHBA and acetoacetate (Kauppinen, 1983). Conceivably, subclinical ketosis may start at levels of BHBA 
greater than 1,000 $\mathrm{mmol} / \mathrm{L}$; however, the decision to set an appropriate subclinical threshold using serum or plasma BHBA appears to be somewhat arbitrary. Kelly (1977) suggested that 1,000 $\mathrm{mol} / \mathrm{L}$ be used to separate cows with low and high BHBA concentrations. Nielen et al. (1994) selected a subclinical ketosis threshold of $1,200 \mu \mathrm{mol} / \mathrm{L}$ of BHBA based on the data appearing to be skewed around that value.

Because increased ketone bodies postcalving are considered to be part of a normal metabolic response to increased energy demand, it seems that a cutpoint to define high ketone body concentrations should be based on production or health impairment. Other authors have recently identified more objective cutpoints for defining hyperketonemia. Risk of abomasal displacement was identified at serum BHBA concentrations of 1,200 $\mu \mathrm{mol} / \mathrm{L}$ (Geishauser et al., 1997; LeBlanc et al., 2005).

Ketone utilization by cells is a normal part of dairy cow metabolism. In fact individual capacity to handle elevated ketones may vary from cow to cow. Despite this limitation, elevations in ketone body concentrations are likely reasonable surrogate indicators of impaired energy metabolism. For useful implementation of this concept, objective thresholds for defining hyperketonemia at the cow and herd level are required. The purpose of this paper is to identify a critical threshold of serum BHBA for defining hyperketonemia at the cow level based on impaired production or cow health.

\section{MATERIALS AND METHODS}

The main objective of the overall study was to assess the efficacy of a monensin controlled-release capsule on indicators of energy metabolism and cow health in lactating dairy cattle. Details of the study design have been described previously (Duffield et al., 1998). Briefly, a total of 1,010 cows from 25 farms were treated with either monensin or a placebo CRC (Rumensin CRC, Elanco, a division of Eli Lilly Canada, Guelph, Ontario, Canada) at 3 wk before expected calving. The herd size ranged from 25 to 160 milking cows; feeding management included 5 TMR-fed herds and 20 component-fed herds. Four herds had freestall housing; the other 21 were tie-stall.

\section{Sample Collection}

A blood sample was obtained at the time of treatment administration and at wk 1, 2, 3, 6, and 9 postcalving. After collection, blood samples were stored in an insulated cooler and returned to the Ontario Veterinary College for processing within $5 \mathrm{~h}$ postcollection. Blood was centrifuged at $733 \times g$ for $10 \mathrm{~min}$, and harvested serum was evaluated for BHBA concentrations. For the purpose of the current analysis, only data on BHBA from the first or second week postcalving were utilized. Analysis was limited to the first 2 wk postpartum because a previous evaluation had determined the peak concentrations of BHBA to be in these weeks (Duffield et al., 1998) and because using data beyond the first 2 wk postpartum made time ordering serum before disease diagnosis or first DHI milk test difficult and would result in substantial loss of data. The BHBA was measured using an automated analyzer (Dacos 2 Analyzer, Coulter Electronics, Hialeah, FL) and a reagent supplied by Sigma Diagnostics (St. Louis, MO). Hemolysis of serum was recorded on a qualitative scale of 0 (none) to 3 (dark) as described previously (Duffield et al., 1998). Significant interference of measurement of BHBA (hemolysis score 2 and above) was present in less than $3 \%$ of samples and was not a significant factor in any of the models presented; thus the influence of serum hemolysis was ignored.

\section{Disease Recording}

Disease information was collected by use of on-farm diaries, computer recorded events, veterinary visit summaries and weekly technician visit recordings. All occurrences of disease were recorded for the first $95 \mathrm{~d}$ of lactation. The 4 diseases of interest for the purpose of the current study were clinical ketosis $(\mathbf{C K})$, displaced abomasum (DA), metritis, and clinical mastitis (CM). In addition, diseases that occurred at the time of calving (retained placenta, milk fever, dystocia) were utilized as potential covariates in statistical models. Definitions for these diseases have been described previously (Duffield et al., 1999). Clinical ketosis in this study was defined as a veterinary diagnosis based on a reduced feed intake, testing positive for a nitroprusside-based milk ketone test, and the absence of any other disease. Metritis was a veterinary diagnosis of uterine inflammation occurring before 15 DIM; displaced abomasum was a veterinary diagnosis of a right- or left-side abomasal displacement; and mastitis was defined as any cow recorded as having abnormal milk.

\section{Milk Recording}

All herds on this project were enrolled in a DHI milk recording program where milk production and other data are recorded on-farm at intervals of approximately 35 to 40 d. Data collection included milk yield (kg), milk fat percentage, milk protein percentage, days in milk at DHI test day, and SCC linear score. 


\section{Statistical Analysis}

Appropriate thresholds for defining hyperketonemia based on serum BHBA levels associated with increased risk of cow health events were determined first by creating incremental cutpoints of $200 \mu \mathrm{mol} / \mathrm{L}$ of BHBA from 600 to $2,000 \mu \mathrm{mol} / \mathrm{L}$. These cutpoints were evaluated using dichotomous variables, designating a 0 value for all samples below each cutpoint and assigning a value of 1 to all values at or above each cutpoint. These serial thresholds were then contrasted with the occurrence of clinical disease using simple $2 \times 2$ contingency tables. For all disease analysis, data were time ordered so that only data for which serum was obtained at least $1 \mathrm{~d}$ before the disease diagnosis were included. All other disease data were discarded for each disease evaluation where the sample was obtained on or after disease diagnosis. Using disease occurrence as the gold standard, sensitivity and specificity for each cutpoint for each disease were calculated. The serum BHBA threshold having the greatest sum of sensitivity and specificity was selected for further logistic regression analysis. Logistic regression models were constructed using the threshold of serum BHBA identified from the $2 \times 2$ table screening process. In addition, the following variables were offered to the model and removed if not significant $(P>0.05)$ or retained if removal caused more than a $25 \%$ change in the other model coefficients: parity, precalving BCS $\geq 4.0$ (fat), precalving BCS $\leq 3.0$ (thin), dystocia, milk fever, retained placenta. Treatment with monensin was forced into the displaced abomasum model because it had previously been significantly associated with a reduction in occurrence. However, this variable was offered and removed in the same way as the other variables for CK, CM, and metritis. All plausible 2-way interactions between the cutpoint and other remaining significant variables were tested and removed if not significant $(P<0.05)$. All health models were analyzed using logistic regression controlling for potential clustering of cows within herd using generalized estimating equations. Logistic regression analysis using the logistic link function and a binary distribution with a compound symmetry correlation structure was conducted using Proc Genmod (SAS Institute, 2004).

A similar type of analysis and approach was conducted for identifying a threshold value of serum BHBA associated with a change in milk production. A data set was created from DHI test day information and serum BHBA levels from cows with serum samples measured before milk yield measurement at the first DHI test. Hierarchical dummy variables were created in the same manner as described for the logistic models and ranged from 600 to $2,000 \mu \mathrm{mol} / \mathrm{L}$ of BHBA. A linear regres- sion model was used with test day milk production as the dependent variable. Days in milk at DHI test, parity, linear score and season of calving, and precalving BCS were included as independent effects. Herd was included in each model as a random effect, and treatment with monensin was forced into all models. Each dummy variable for serum BHBA was offered to the model and then removed in a forward stepwise approach. The BHBA threshold for the dummy variable having a negative $\beta$ coefficient and the least $P$-value was chosen as the threshold for defining hyperketonemia. Choosing this threshold helps to minimize the chance of a type 1 error. The same approach was used for test day milk fat and milk protein percentage. A subsequent series of regressions were conducted on the 305-d milk yield data projected at the third DHI test. All of the above models were analyzed using Proc Mixed in SAS (SAS Institute, 2004). These models were defined by the general equation

$$
\begin{aligned}
\mathrm{Y}_{\mathrm{ijklm}}=\beta_{0} & +\beta_{1} \mathrm{X}_{1}+\beta_{2} \mathrm{X}_{2}+\alpha_{\mathrm{i}}+\rho_{\mathrm{j}}+\gamma_{\mathrm{k}} \\
& +\sigma_{1}+\mathrm{H}_{\mathrm{m}}+\mathrm{e}_{\mathrm{ijklmn}},
\end{aligned}
$$

where $Y_{\mathrm{ijklm}}=$ the milk production (or milk fat or protein percentage) of cow with factors ijkl in herd $\mathrm{m} ; \beta_{0}=$ the intercept; $\mathrm{X}_{1}=$ days in milk, $\mathrm{X}_{2}=$ linear score, $\alpha_{\mathrm{i}}=$ monensin treatment [(i $=0$ (monensin) or 1 (control)], $\rho_{\mathrm{j}}=$ precalving body condition score $[\mathrm{j}=1$ to 3 (thin, good, fat)], $\gamma_{\mathrm{k}}=$ season of calving ( $\mathrm{k}=1$ to 4$), \sigma_{1}=$ BHBA threshold $\left[\sigma=0\right.$ (below), 1 (at or above)], $\mathrm{H}_{\mathrm{m}}=$ random herd effect, and $\mathrm{e}_{\mathrm{ijklmn}}=$ random error term.

In all cases, thresholds of BHBA were identified from serum obtained from each of wk 1 and wk 2 postcalving. All 2-way interactions between BHBA threshold and other covariates were tested and retained if significant at $P<0.05$. All analysis included data from any cows that were diagnosed with CK (maximum of 15 cows recorded). Thus, we refer to the impact of hyperketonemia rather than subclinical ketosis.

\section{RESULTS}

\section{Disease}

Serum samples were obtained a median of 4 and 11 d postpartum for wk 1 and 2 samples, respectively. The data included a total of 997 calvings, but the denominator changed depending on the disease outcome because the blood sampling must have preceded the disease diagnosis. There were a total of 32 DA, 13 CK, $103 \mathrm{CM}$, and 27 metritis events to evaluate the association between wk 1 postpartum serum BHBA and disease occurrence. Serum samples were obtained at a 
Table 1. Evaluation of the risk of displaced abomasum (LDA) and univariate associations with serum BHBA obtained in either wk 1 or 2 postpartum $^{1}$

\begin{tabular}{|c|c|c|c|c|c|c|c|c|c|}
\hline $\begin{array}{l}\text { BHBA } \\
\text { cutpoint } \\
(\mu \mathrm{mol} / \mathrm{L})\end{array}$ & $\begin{array}{c}\text { Proportion } \\
\text { of cows } \\
\text { at/above } \\
\text { cutpoint }\end{array}$ & $\begin{array}{l}\text { Risk of } \\
\text { LDA at } \\
\text { or above } \\
\text { cutpoint }\end{array}$ & $\begin{array}{l}\text { Risk of } \\
\text { LDA below } \\
\text { cutpoint }\end{array}$ & $\begin{array}{l}\text { Odds } \\
\text { ratio }\end{array}$ & $95 \% \mathrm{CI}$ & $P$-value & $\begin{array}{c}\text { Sensitivity } \\
(\%)\end{array}$ & $\begin{array}{c}\text { Specificity } \\
(\%)\end{array}$ & LR \\
\hline \multicolumn{10}{|c|}{ Wk 1 postpartum $(\mathrm{n}=987)$} \\
\hline 600 & 76.0 & 3.3 & 2.9 & 1.13 & 0.48 to 2.65 & 0.083 & 78.1 & 24.1 & 1.03 \\
\hline 800 & 51.1 & 4.2 & 2.3 & 1.86 & 0.87 to 3.89 & 0.096 & 65.6 & 49.3 & 1.29 \\
\hline 1,000 & 35.5 & 4.8 & 2.3 & 2.11 & 1.04 to 4.27 & 0.034 & 53.1 & 65.0 & 1.52 \\
\hline $1,200^{*}$ & 24.0 & 5.9 & 2.4 & 2.55 & 1.25 to 5.21 & 0.008 & 43.7 & 76.6 & 1.87 \\
\hline 1,400 & 16.2 & 6.9 & 2.5 & 2.83 & 1.34 to 6.00 & 0.005 & 34.3 & 84.4 & 2.20 \\
\hline 1,600 & 11.7 & 7.8 & 2.6 & 3.10 & 1.40 to 6.88 & 0.003 & 28.1 & 88.8 & 2.51 \\
\hline 1,800 & 9.6 & 7.4 & 2.8 & 2.76 & 1.16 to 6.56 & 0.017 & 21.9 & 90.7 & 2.37 \\
\hline 2,000 & 7.6 & 5.3 & 3.1 & 1.78 & 0.61 to 5.21 & 0.287 & 12.5 & 92.6 & 1.68 \\
\hline \multicolumn{10}{|c|}{ Wk 2 postpartum $(\mathrm{n}=941)$} \\
\hline 600 & 77.2 & 2.3 & 1.4 & 1.68 & 0.49 to 5.80 & 0.4038 & 85.0 & 22.9 & 1.10 \\
\hline 800 & 52.0 & 2.9 & 1.3 & 2.19 & 0.83 to 5.75 & 0.1027 & 70.0 & 48.4 & 1.36 \\
\hline 1,000 & 34.0 & 4.1 & 1.1 & 3.71 & 1.47 to 9.40 & 0.0031 & 65.0 & 66.7 & 1.95 \\
\hline 1,200 & 24.8 & 4.3 & 1.4 & 3.13 & 1.29 to 7.62 & 0.0082 & 50.0 & 75.8 & 2.06 \\
\hline 1,400 & 18.6 & 5.1 & 1.4 & 3.72 & 1.52 to 9.12 & 0.0022 & 45.0 & 82.0 & 2.50 \\
\hline 1,600 & 14.6 & 6.6 & 1.4 & 5.07 & 2.06 to 12.47 & 0.0001 & 45.0 & 86.1 & 3.24 \\
\hline $1,800^{*}$ & 12.3 & 7.8 & 1.3 & 6.22 & 2.52 to 15.37 & 0.0001 & 45.0 & 88.4 & 3.87 \\
\hline 2,000 & 10.5 & 8.1 & 1.4 & 6.08 & 2.42 to 15.26 & 0.0001 & 40.0 & 90.1 & 4.05 \\
\hline
\end{tabular}

${ }^{1} \mathrm{CI}=$ confidence interval; $\mathrm{LR}=$ likelihood ratio.

*Optimum cutpoint based on maximum sensitivity and specificity.

median of 12.5, 9, 20, and $6 \mathrm{~d}$ before disease diagnosis for DA, CK, CM, and metritis, respectively. Week 1 BHBA was associated with subsequent diagnosis of DA, CK, and metritis but not CM. Simple associations between the threshold values of serum BHBA obtained in wk 1 postpartum and the occurrence of DA, CK, and metritis are found in Tables 1, 2, and 3, respectively.
Optimum BHBA cutpoints based on the maximum total of sensitivity and specificity were $1,200 \mu \mathrm{mol} / \mathrm{L}$ for DA and metritis occurrence, and 1,400 $\mu \mathrm{mol} / \mathrm{L}$ for CK.

There was a reduced data set for evaluation of serum BHBA values obtained in wk 2 postpartum and subsequent risk of disease because of the necessity to

Table 2. Evaluation of the risk of clinical ketosis and univariate associations with serum BHBA obtained in wk 1 or 2 postpartum ${ }^{1}$

\begin{tabular}{|c|c|c|c|c|c|c|c|c|c|}
\hline $\begin{array}{l}\text { BHBA } \\
\text { cutpoint } \\
(\mu \mathrm{mol} / \mathrm{L})\end{array}$ & $\begin{array}{c}\text { Proportion } \\
\text { of cows } \\
\text { at/above } \\
\text { cutpoint } \\
(\%)\end{array}$ & $\begin{array}{c}\text { Risk of } \\
\text { ketosis at } \\
\text { or above } \\
\text { cutpoint } \\
(\%)\end{array}$ & $\begin{array}{l}\text { Risk of } \\
\text { ketosis } \\
\text { below } \\
\text { cutpoint } \\
(\%)\end{array}$ & $\begin{array}{l}\text { Odds } \\
\text { ratio }\end{array}$ & $95 \% \mathrm{CI}$ & $P$-value & $\begin{array}{c}\text { Sensitivity } \\
(\%)\end{array}$ & $\begin{array}{c}\text { Specificity } \\
(\%)\end{array}$ & LR \\
\hline \multicolumn{10}{|c|}{ Wk 1 postpartum $(\mathrm{n}=972)$} \\
\hline 600 & 78.0 & 1.4 & 0.9 & 1.54 & 0.34 to 7.01 & 0.7448 & 84.6 & 21.9 & 1.08 \\
\hline 800 & 52.5 & 1.7 & 0.9 & 2.02 & 0.62 to 6.61 & 0.2741 & 69.2 & 47.3 & 1.31 \\
\hline 1,000 & 36.5 & 2.2 & 0.8 & 2.76 & 0.90 to 8.50 & 0.0831 & 61.5 & 63.3 & 1.70 \\
\hline 1,200 & 24.6 & 2.9 & 0.8 & 3.53 & 1.18 to 10.62 & 0.0246 & 53.8 & 75.2 & 2.17 \\
\hline $1,400^{*}$ & 16.6 & 3.6 & 0.9 & 4.25 & 1.41 to 12.81 & 0.0141 & 46.1 & 83.2 & 2.75 \\
\hline 1,600 & 12.1 & 3.3 & 1.1 & 3.17 & 0.96 to 10.45 & 0.0685 & 30.8 & 87.7 & 2.50 \\
\hline 1,800 & 9.9 & 4.1 & 1.0 & 4.09 & 1.24 to 13.54 & 0.0340 & 30.8 & 90.2 & 3.14 \\
\hline 2,000 & 7.8 & 3.8 & 1.1 & 3.54 & 0.95 to 13.12 & 0.0792 & 23.1 & 92.2 & 2.95 \\
\hline \multicolumn{10}{|c|}{ Wk 2 postpartum $(\mathrm{n}=951)$} \\
\hline 600 & 77.2 & 0.4 & 0.9 & 2.43 & 0.29 to 20.27 & 0.6801 & 85.7 & 28.8 & 1.20 \\
\hline 800 & 52.0 & 0.6 & 0.8 & 1.32 & 0.29 to 5.91 & 1.0000 & 57.1 & 49.7 & 1.14 \\
\hline 1,000 & 34.0 & 1.2 & 0.5 & 2.59 & 0.58 to 11.63 & 0.2386 & 57.1 & 66.0 & 1.68 \\
\hline 1,200 & 24.8 & 1.7 & 0.4 & 4.09 & 0.90 to 18.42 & 0.0681 & 57.1 & 75.4 & 2.32 \\
\hline $1,400^{*}$ & 18.6 & 2.3 & 0.4 & 5.98 & 1.33 to 27.00 & 0.0250 & 57.1 & 81.8 & 3.14 \\
\hline 1,600 & 14.6 & 2.2 & 0.5 & 4.46 & 0.99 to 20.13 & 0.0684 & 42.9 & 85.6 & 2.97 \\
\hline 1,800 & 12.3 & 2.5 & 0.5 & 5.41 & 1.19 to 24.46 & 0.0448 & 42.9 & 87.8 & 3.52 \\
\hline 2,000 & 10.5 & 3.0 & 0.5 & 6.47 & 1.43 to 29.35 & 0.0296 & 42.9 & 89.6 & 4.13 \\
\hline
\end{tabular}

${ }^{1} \mathrm{CI}=$ confidence interval; $\mathrm{LR}=$ likelihood ratio.

*Optimum based on test performance (sum of sensitivity and specificity). 
Table 3. Evaluation of the risk of metritis and univariate associations with serum BHBA obtained wk 1 postpartum ${ }^{1}$

\begin{tabular}{|c|c|c|c|c|c|c|c|c|c|}
\hline $\begin{array}{l}\text { BHBA } \\
\text { cutpoint } \\
(\mu \mathrm{mol} / \mathrm{L})\end{array}$ & $\begin{array}{c}\text { Proportion } \\
\text { of cows } \\
\text { at/above } \\
\text { cutpoint } \\
(\%)\end{array}$ & $\begin{array}{l}\text { Risk of } \\
\text { metritis at } \\
\text { or above } \\
\text { cutpoint } \\
(\%)\end{array}$ & $\begin{array}{l}\text { Risk of } \\
\text { metritis } \\
\text { below } \\
\text { cutpoint } \\
(\%)\end{array}$ & $\begin{array}{l}\text { Odds } \\
\text { ratio }\end{array}$ & $95 \%$ CI & $P$-value & $\begin{array}{c}\text { Sensitivity } \\
(\%)\end{array}$ & $\begin{array}{c}\text { Specificity } \\
(\%)\end{array}$ & $\mathrm{LR}$ \\
\hline \multicolumn{10}{|c|}{ Week 1 postpartum $(\mathrm{n}=961)$} \\
\hline 600 & 78.0 & 2.9 & 2.4 & 1.22 & 0.46 to 3.27 & 0.6891 & 81.5 & 21.7 & 1.04 \\
\hline 800 & 52.5 & 3.9 & 1.5 & 2.62 & 1.10 to 6.26 & 0.0245 & 74.1 & 47.9 & 1.42 \\
\hline 1,600 & 12.1 & 6.7 & 2.3 & 3.09 & 1.32 to 7.23 & 0.0063 & 29.6 & 88.0 & 2.47 \\
\hline 1,800 & 9.9 & 6.2 & 2.4 & 2.68 & 1.05 to 6.81 & 0.0315 & 22.2 & 90.4 & 2.31 \\
\hline 2,000 & 7.8 & 6.6 & 2.5 & 2.76 & 1.02 to 7.51 & 0.0551 & 18.5 & 92.4 & 2.44 \\
\hline
\end{tabular}

${ }^{1}$ No significant associations were found for wk 2 postpartum. CI = confidence interval; LR = likelihood ratio.

*Optimum threshold based on maximum sensitivity and specificity.

time-order serum sampling before disease diagnosis. As a result, there were a total of $20 \mathrm{DA}, 7 \mathrm{CK}, 75 \mathrm{CM}$, and 6 metritis events to analyze. Samples were obtained a median of $8,20,29$, and $2.5 \mathrm{~d}$ before disease diagnosis for DA, CK, CM, and metritis, respectively. Week 2 BHBA was associated with subsequent diagnosis of DA and CK but not CM or metritis. Simple associations between the threshold values of serum BHBA obtained in wk 2 postpartum, and DA and CK occurrence are found in Tables 1 and 2. Optimum BHBA cutpoints based on the maximum total of sensitivity and specificity were $1,800 \mu \mathrm{mol} / \mathrm{L}$ for $\mathrm{DA}$ and $1,400 \mu \mathrm{mol} / \mathrm{L}$ for CK.

Logistic regression models on the risk of DA, CK, and metritis are presented in Tables 4, 5, and 6, respectively. All thresholds previously identified in the simple analysis remained statistically significant in these models with small changes in the odds of dis- ease occurrence. Significant covariates for each model varied by week and by disease outcome. Parity was a significant covariate for the both the wk $1 \mathrm{DA}$ and wk 1 metritis models. Retained placenta was also significantly associated with the risk of metritis. In addition, precalving BCS was a significant factor influencing the risk of metritis. Occurrence of milk fever and retained placenta were associated with the risk of DA in the wk 2 model and dystocia was associated with the wk 1 CK model.

\section{Milk Production}

BHBA values from the wk 1 and wk 2 blood samplings were obtained an average of 21 and $14 \mathrm{~d}$ before first test day DHI milk yield measurements, respectively. The effect of increasing threshold of serum BHBA on milk yield for wk 1 and wk 2 serum samples are presented

Table 4. Final logistic models for optimum cutpoints of serum BHBA postpartum and risk of displaced abomasum $^{1}$

\begin{tabular}{|c|c|c|c|c|}
\hline Variable & Estimate & SE & Odds ratio & $P$-value \\
\hline \multicolumn{5}{|l|}{ Wk 1 postpartum } \\
\hline Intercept & -3.0817 & 0.324 & 0.046 & $<0.001$ \\
\hline Monensin treatment & -0.5586 & 0.393 & 0.572 & 0.155 \\
\hline Placebo treatment & Referent & & & \\
\hline $\mathrm{BHBA} \geq 1,200 \mu \mathrm{mol} / \mathrm{L}$ & 0.7754 & 0.288 & 2.17 & 0.007 \\
\hline Parity 1 & -0.1566 & 0.326 & 0.855 & 0.631 \\
\hline Parity 2 & -1.7602 & 0.703 & 0.172 & 0.012 \\
\hline Parity 3 & Referent & & & \\
\hline \multicolumn{5}{|l|}{ Wk 2 postpartum } \\
\hline Intercept & -4.434 & 0.5013 & 0.0012 & $<0.001$ \\
\hline Monensin treatment & -0.6658 & 0.4959 & 0.514 & 0.1795 \\
\hline Placebo treatment & Referent & & & \\
\hline $\mathrm{BHBA} \geq 1,800 \mu \mathrm{mol} / \mathrm{L}$ & 1.9415 & 0.5979 & 6.97 & 0.0012 \\
\hline Retained placenta & 1.4166 & 0.6094 & 4.12 & 0.0201 \\
\hline No retained placenta & Referent & & & \\
\hline Milk fever & 1.2530 & 0.5971 & 3.50 & 0.0359 \\
\hline No milk fever & Referent & & & \\
\hline
\end{tabular}

${ }^{1}$ Separate models were investigated for serum obtained in wk 1 and 2 postpartum. 
Table 5. Final logistic models for optimum cutpoints of serum BHBA postpartum and risk of clinical ketosis

\begin{tabular}{lcccc}
\hline Variable & Estimate & SE & Odds ratio & $P$-value \\
\hline Wk 1 postpartum & & & & \\
Intercept & -4.7806 & 0.5012 & 0.008 & $<0.001$ \\
BHBA $\geq 1,400 \mu \mathrm{mol} / \mathrm{L}$ & 1.4407 & 0.6253 & 4.22 & 0.0212 \\
Dystocia & 1.8851 & 0.8320 & 6.59 & 0.0258 \\
No dystocia & Referent & & & \\
Wk 2 postpartum & & & 0.004 & $<0.001$ \\
Intercept & -5.4845 & 0.6477 & 6.48 & 0.0266 \\
BHBA $\geq 1,400 \mu \mathrm{mol} / \mathrm{L}$ & 1.8694 & 0.8432 & \\
\hline
\end{tabular}

in Table 7. Elevations in serum BHBA in both wk 1 and wk 2 postpartum had a negative impact on milk yield. Optimum thresholds of serum BHBA were 1,400 $\mu \mathrm{mol} / \mathrm{L}$ for wk 1 and 2,000 $\mu \mathrm{mol} / \mathrm{L}$ for wk 2 , respectively.

In addition to milk yield, there were significant associations found between serum BHBA and first DHI test day milk fat and milk protein percentage. Cows with elevated serum BHBA in wk 1 or 2 postpartum had increased milk fat percentage and decreased milk protein percentage. Optimum cutpoints for milk fat percentage defined as the combination of the greatest magnitude of effect with largest significance (least $P$-value) were wk $1-1,200 \mu \mathrm{mol} / \mathrm{L}$ (increased milk fat by an absolute value of $0.22 \%$ ) and wk $2-2,000 \mu \mathrm{mol} / \mathrm{L}$ (increased milk fat percentage by an absolute value of $0.48 \%$ ). Similarly, optimum cutpoints for milk protein percentage were wk $1-2,000 \mu \mathrm{mol} / \mathrm{L}$ of BHBA (decreased milk protein percentage by an absolute value of $0.09 \%$ ) and wk 2-1,000 $\mu \mathrm{mol} / \mathrm{L}$ of BHBA (decreased milk protein percentage by an absolute value of $0.09 \%$ ).

In addition to DHI test day milk yield, the influence of elevations in early lactation ketone bodies on projected 305-d milk yield at third DHI test day was assessed. The results of this analysis are presented in Table 8 . These data provide contradictory findings. There was a negative impact of elevations in ketone bodies in wk 1 postpartum on projected 305-d milk yield, with linear negative effects beginning at $1,200 \mu \mathrm{mol} / \mathrm{L}$, and an optimum cutpoint of $1,800 \mu \mathrm{mol} / \mathrm{L}$ causing a loss of over $300 \mathrm{~kg}$ for a lactation. However, increasing ketones in wk 2 postpartum was associated with increased milk yield, with an optimum cutpoint of $1,000 \mu \mathrm{mol} / \mathrm{L}$ being associated with $270 \mathrm{~kg}$ more milk during a projected 305-d lactation. Increasing BHBA concentration above $1,000 \mu \mathrm{mol} / \mathrm{L}$ during wk 2 postpartum was associated with progressively less $305-\mathrm{d}$ milk yield benefit, but still was numerically above $100 \mathrm{~kg}$ during a lactation at a threshold of 2,000 $\mu \mathrm{mol} / \mathrm{L}$ of serum BHBA.

To try to understand these differences, graphs of milk yield by test day for cows having serum BHBA below or at/above a cutpoint of $1,400 \mu \mathrm{mol} / \mathrm{L}$ for wk 1 and 2 postpartum were plotted for the first 3 DHI tests (Figures 1 and 2, respectively)

\section{DISCUSSION}

\section{Disease}

The results of this analysis suggest that important thresholds for defining hyperketonemia for predicting health risk in early lactation dairy cows begin at a concentration of serum BHBA $\geq 1,200 \mu \mathrm{mol} / \mathrm{L}$. This observation with respect to DA risk is consistent with the findings of LeBlanc et al. (2005). The exact mechanism that explains why cows diagnosed with DA have

Table 6. Final logistic models for optimum cutpoints of serum BHBA postpartum and risk of metritis ${ }^{1}$

\begin{tabular}{lcccc}
\hline & \multicolumn{3}{c}{ Wk 1 postpartum } \\
\cline { 2 - 5 } Variable & Estimate & SE & Odds ratio & $P$-value \\
\hline Intercept & -3.5522 & 0.3265 & 0.03 & $<0.001$ \\
BHBA $\geq 1,200 \mu \mathrm{mol} / \mathrm{L}$ & 0.9468 & 0.3330 & 0.58 & 0.0045 \\
Parity 1 & -1.4497 & 0.6737 & 0.23 & 0.0314 \\
Parity 2 & -0.5318 & 0.4309 & 0.59 & 0.2171 \\
Parity 3 & Referent & & 1.40 & $<0.001$ \\
Retained placenta & 0.3383 & 0.3875 & 0.14 & 0.0014 \\
No retained placenta & Referent & & 0.6084 & 0.1429 \\
BCS - fat & -1.938 & 0.3930 & & \\
BCS - good & -0.576 & & & \\
BCS - thin & Referent & & &
\end{tabular}

${ }^{1}$ No association found for metritis and serum BHBA obtained during wk 2 postpartum. 


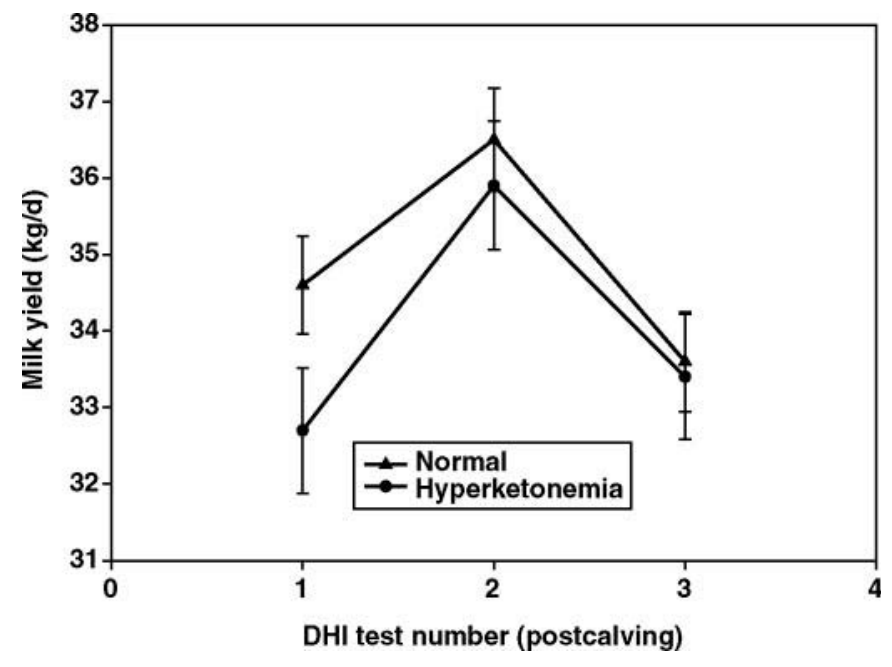

Figure 1. Least squares means $\pm \mathrm{SE}$ of milk yield $(\mathrm{kg} / \mathrm{d})$ from the mixed procedure (SAS Institute, 2004), stratified by test day for a threshold of $1,400 \mu \mathrm{mol} / \mathrm{L}$ of serum BHBA obtained during wk 1 postcalving (hyperketonemia) compared with cows having less than $1,400 \mu \mathrm{mol} / \mathrm{L}$ serum BHBA (normal).

elevations in BHBA on average $12 \mathrm{~d}$ before diagnosis is not well understood. One possibility is that the factors contributing to greater ketone bodies have similar causal etiologic pathways as that of DA. It is probable that these cows are not eating well. Therefore, these animals are suffering a poor adaptive response to the onset of lactation and to the resulting negative energy balance. Lack of rumen fill has been suggested as risk factor for occurrence of DA (Shaver, 1997). VanWinden et al. (2003) have described potential influences of reduced insulin and glucose concentrations (which typically occur concomitantly with increased BHBA) on abomasal motility and gases that may increase DA risk. It is also possible that there may be some direct effects of greater concentrations of serum BHBA that increase DA risk, but to our knowledge these effects are presently unknown, if they actually do exist.

The finding of elevated ketones preceding and increasing the subsequent risk of CK is supported by other studies (Dohoo and Martin, 1984; Lean et al., 1994). The diagnosis of CK can easily suffer from misclassification through a failure to identify true clinical cows in a herd or falsely identifying clinical cows as a result of vague clinical signs and a poor disease definition (Lean et al., 1994). A serum BHBA threshold that identifies hyperketonemia is an objective means of comparing herd performance and may offer utility in monitoring, treatment, and prevention programs.

The association between increased ketones and subsequent diagnosis of metritis was described previously by Dohoo and Martin (1984). In addition, work by Hammon et al. (2006) described similar effects for ketones on subclinical endometritis. The most likely explanation of this finding is an indirect effect of elevated BHBA on metritis risk mediated through impacts of hyperketonemia on immune function (Suriyasathaporn et al., 2000). However, decreases in DMI have been identified several weeks precalving in cows subsequently diagnosed with metritis postcalving (Huzzey et al., 2007). Less DMI precalving likely results in greater NEFA precalving and consequently greater BHBA concentrations postcalving (Osborne, 2003). The lack of an association for

Table 7. The impact of elevated serum BHBA on first DHI test milk yield ${ }^{1}$

\begin{tabular}{|c|c|c|c|c|}
\hline $\begin{array}{l}\text { Threshold BHBA } \\
(\mu \mathrm{mol} / \mathrm{L})\end{array}$ & $\begin{array}{l}\text { Milk yield for cows } \\
\text { below threshold }\end{array}$ & $\begin{array}{l}\text { Milk yield for cows at } \\
\text { or above threshold }\end{array}$ & $\begin{array}{l}\text { Difference in yield for cows } \\
\text { at or above threshold }\end{array}$ & $P$-value \\
\hline \multicolumn{5}{|c|}{ Serum sample obtained during wk 1 postpartum } \\
\hline 600 & 33.08 & 34.69 & +1.61 & 0.0050 \\
\hline 1,000 & 34.60 & 33.78 & -0.82 & 0.0985 \\
\hline 1,200 & 34.61 & 33.39 & -1.22 & 0.0294 \\
\hline $1,400^{*}$ & 34.61 & 32.73 & -1.88 & 0.0030 \\
\hline 2,000 & 34.41 & 33.07 & -1.34 & 0.1266 \\
\hline \multicolumn{5}{|c|}{ Serum sample obtained during wk 2 postpartum } \\
\hline 600 & 34.52 & 35.57 & +1.05 & 0.084 \\
\hline 800 & 35.02 & 35.49 & +0.47 & 0.3938 \\
\hline 1,000 & 35.27 & 35.27 & 0 & 0.9996 \\
\hline 1,200 & 35.51 & 34.48 & -1.03 & 0.1009 \\
\hline 1,400 & 35.52 & 34.13 & -1.39 & 0.0372 \\
\hline
\end{tabular}

${ }^{1}$ Least squares means derived from a mixed model (Proc Mixed, SAS Institute, 2004). Model adjusted for the random effect of herd and the fixed effects of parity, DIM, BCS, SCC linear score, season of calving, and monensin treatment, using Proc Mixed in SAS version 9.0.

*Optimum threshold based on combination of least $P$-value and greatest magnitude of effect indicated with an asterisk. 
metritis and BHBA in the second week postcalving is best explained by a low sample size with only 6 cows having metritis in the data set for this time period. The disease definition of metritis in this study included a restriction of no more than 14 DIM for classifying a uterine infection as metritis.

Given the potential for immune function impairment, there was an expectation of impacts of elevated BHBA on risk of $\mathrm{CM}$. Lack of an association in this study could be a function of both underreporting of mastitis and a wide risk interval (up to $95 \mathrm{~d}$ in milk) compared with the other 3 diseases (DA, CK, and metritis) which predominantly occur within the first month postpartum. A meta-analysis on the use of monensin through the transition period has demonstrated that it reduced NEFA, ketones, and elevated glucose (Duffield et al., 2008a). In addition, over all the trials analyzed, monensin decreased the risk of CK, DA, and CM (Duffield et al., 2008b). Monensin was included as a covariate in the DA model for the current paper because it had been previously shown to reduce the risk of DA from the same data. Including or excluding monensin in the model made little difference to the model or parameter estimates. Monensin was not statistically significant in this model because of a loss of power from losing data through time-ordering the blood sampling and disease.

Although attempts were made to appropriately timeorder blood samples and disease occurrence by deleting data where disease occurred before blood sampling within wk 1 or 2 , a failure to diagnose the condition early in the disease process could affect the presumed time ordering of the blood sample before diagnosis. In

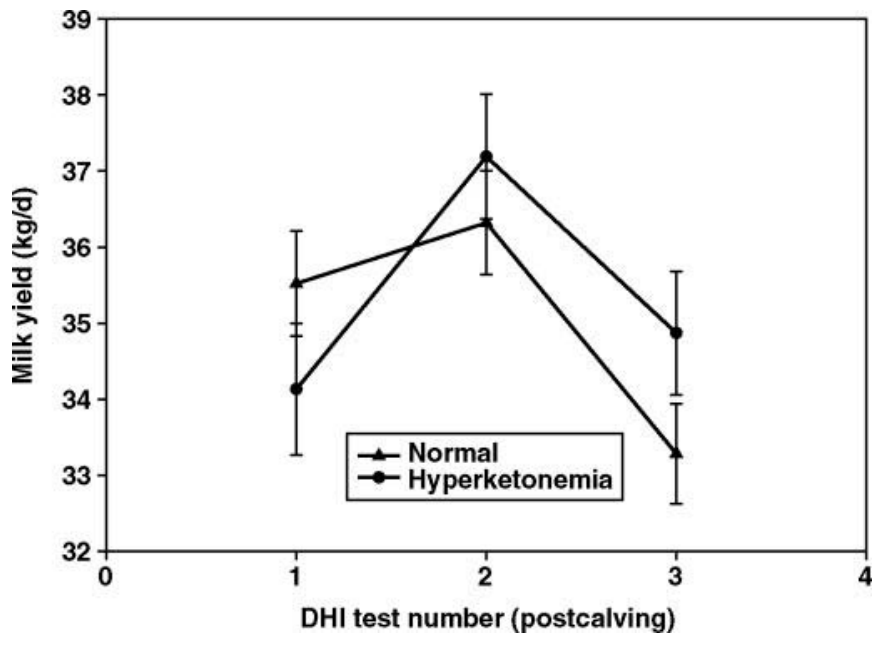

Figure 2. Least squares means $\pm \mathrm{SE}$ of milk yield $(\mathrm{kg} / \mathrm{d})$ from the mixed procedure (SAS Institute, 2004), stratified by test day for a threshold of $1,400 \mu \mathrm{mol} / \mathrm{L}$ of serum BHBA obtained during wk 2 postcalving (hyperketonemia) compared with cows having less than $1,400 \mu \mathrm{mol} / \mathrm{L}$ serum BHBA (normal).

some cases the animal may have had the disease condition at the same time or even before the blood sampling. Thus, the associations measured might partly be an effect of the disease rather than increased serum BHBA being part of the causal pathway for disease occurrence. However, the above-mentioned precalving associations with NEFA and postcalving increases in disease risk and serum BHBA, and the described associations with monensin, BHBA, and disease support the latter argument.

Table 8. The impact of elevated serum BHBA on 305-d milk yield - projected at third DHI test ${ }^{1}$

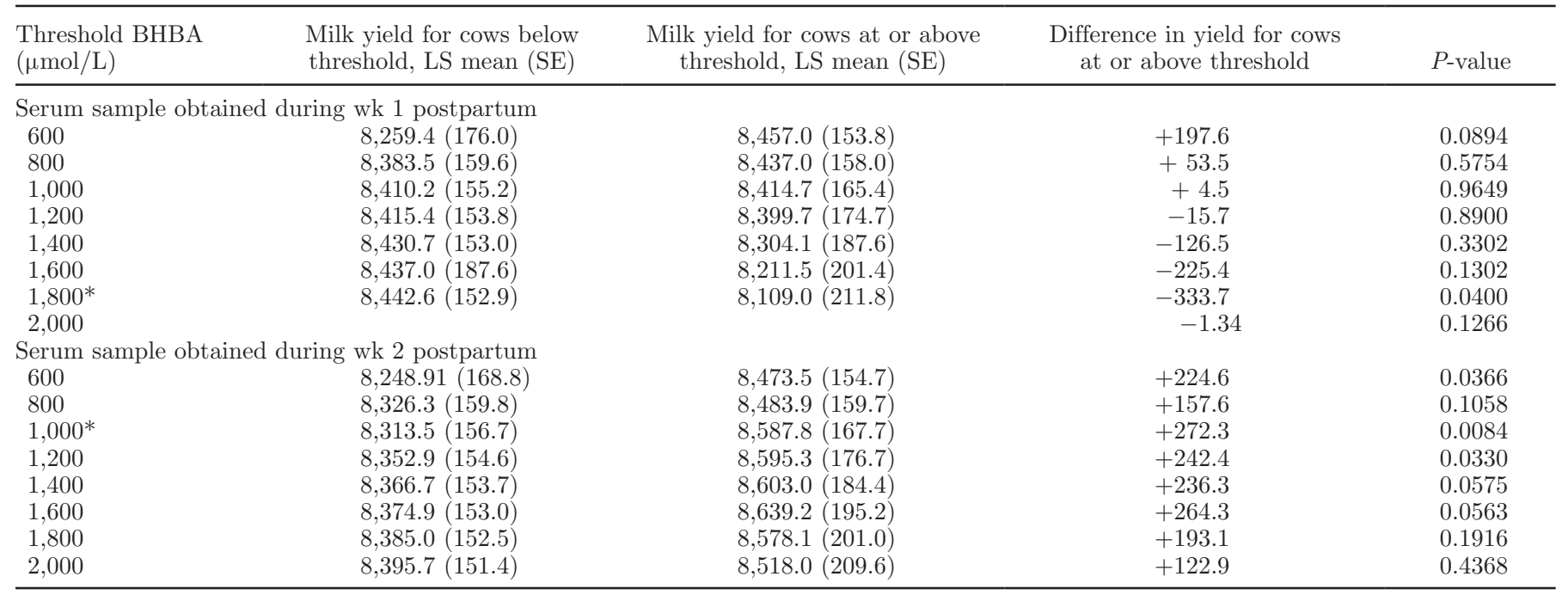

${ }^{1}$ Least squares (LS) means derived from a mixed model (Proc Mixed, SAS Institute, 2004). Model adjusted for the fixed effects of treatment, parity, season of calving and the random effect of herd.

*Optimum thresholds based on greatest magnitude of difference, and smallest $P$-value indicated with an asterisk. 
The odds ratios and significance of critical thresholds for serum BHBA identified in the simple screening process of disease using $2 \times 2$ tables did not change substantially in the logistic regression models. This indicates that despite influences of other covariates and potential disease clustering by farm, these thresholds have practical on-farm value for determining risk. Further, in general the likelihood ratios for subsequent disease risk increased with increasing concentration of serum BHBA suggesting that the greater the cutpoint used, the greater the likelihood of disease.

The different covariates identified for the wk 1 and 2 models of DA may indicate slightly different etiological mechanisms because the median days to diagnosis are different by design for the 2 models. Milk fever and retained placenta were both significant risk factors for the occurrence of DA in the wk-2 model. These associations have been previously demonstrated with path model analysis (Grohn et al., 1989). However, the fact that retained placenta and milk fever were not significant for the wk 1 model might indicate that factors occurring precalving are more important contributors for DA occurrence shortly after calving. LeBlanc et al. (2005) and Cameron et al. (1998) have both identified elevations in precalving NEFA as a risk factor for postcalving DA occurrence.

The differences between the wk 1 and 2 CK models are most likely explained by the low sample size for modeling CK risk in wk 2. Dystocia as a risk factor for ketosis is an interesting finding. Trauma from dystocia might lead to pain, which could lead to inappetance and ketosis. However, dystocia was not directly associated with $\mathrm{CK}$ in at least 2 large path analyses (Curtis et al., 1985; Grohn et al., 1989).

The metritis model suggests a relationship between precalving body condition score and metritis with thin cows (BCS < 3.25) having a greater risk. It is unclear what this association means; however, less DMI might result in less BCS and decreasing DMI precalving has been linked with risk of metritis (Huzzey et al., 2007). The association between retained placenta and metritis is not surprising and has been previously identified (Curtis et al., 1985; Correa et al., 1990).

\section{Milk Yield}

The finding in this study of a reduced milk yield at first DHI test for cows with elevated concentrations of serum BHBA in wk 1 and wk 2 postpartum is consistent with other reports of milk yield losses associated with increased ketones (Dohoo and Martin, 1984; Gustafsson et al., 1993). However, the current study is the first to report milk losses associated with serum BHBA because most other studies reported losses associated with milk ketones. The associations of greater milk fat percentage and less milk protein percentage with increasing ketone concentration was expected and has been previously reported (Miettinen and Setala, 1993; Duffield et al., 1997). The magnitude of the estimated milk yield loss of approximately 1 to $2 \mathrm{~kg} / \mathrm{d}$ is remarkably similar to the estimate of Dohoo and Martin (1984) of 1.0 to 1.4 $\mathrm{kg} / \mathrm{d}$.

The analysis of 305-d projected yield is interesting. There is a marked and contrasting difference in the performance of dairy cows ketotic in wk 1 versus wk 2 of lactation. It appears that having elevated serum BHBA in the first week of lactation is associated with milk loss at both the first DHI test day and for the entire lactation. Lactation yield loss of over $300 \mathrm{~kg}$ for cows having serum BHBA $\geq 1,800 \mu \mathrm{mol} / \mathrm{L}$ is similar to the estimate of Gustafsson et al. (1993) who reported a loss of $328 \mathrm{~kg}$ (fat corrected milk) associated with increased milk acetone. However, projected milk yield of cows with serum BHBA $\geq 1,400 \mu \mathrm{mol} / \mathrm{L}$ in wk 2 postcalving was over $240 \mathrm{~kg}$ greater than cows with less BHBA, yet these same cows with elevated ketone bodies had significantly less milk yield at first DHI test. This apparent contradiction is best explained by the conjecture that greater producing cows are at greater risk of succumbing to ketosis. Elevations in ketones occur in early lactation as an adaptive response to negative energy balance and greater producing cows will have a greater energy demand. Some studies have identified previous lactation milk yield as a risk factor for CK (Grohn et al., 1989; Fleischer et al., 2001), but not all (Grohn et al., 1995; Rajala and Grohn, 1998). The study of Dohoo and Martin (1984) included previous lactation milk yield in their analysis of the impact of milk ketones on milk yield and reported a 1.0 to $1.4 \mathrm{~kg} / \mathrm{d}$ loss associated with a positive milk ketone test. However, in the current study these data were not available.

It is important to note that the approach for selection of thresholds used in this study were conservative and designed to avoid type- 1 errors. If one were to select the first threshold that significantly $(P<0.05)$ decreased milk yield at first DHI test, thresholds of $1,200 \mu \mathrm{mol} / \mathrm{L}$ for wk 1 and 1,400 $\mu \mathrm{mol} / \mathrm{L}$ for wk 2 postpartum would be selected. The differences in the milk production loss or gain patterns for serum BHBA $\geq 1,400 \mu \mathrm{mol} / \mathrm{L}$ are illustrated in Figures 1 and 2. For cows ketotic in the first week, it is clear that milk production is reduced for at least the first 2 DHI tests of lactation and that this loss most likely explains a large part of the full lactation loss. Theoretically, a prevention of ketosis in these animals would result in a milk yield benefit roughly equivalent to this loss. Cows ketotic in wk 2 have less first test milk yield but then have greater second and third test milk yield compared with their nonketotic 
counterparts. It is difficult to know if prevention in these animals would only benefit the early lactation part of this curve, or if there is a more significant potential milk loss that might raise the entire lactation curve itself.

\section{CONCLUSIONS}

From this study it is apparent that hyperketonemia in the first week of lactation is an important risk factor for the subsequent diagnosis of DA, CK, and metritis. Further, at the same time, there is a significant milk loss associated with hyperketonemia. Increased health risk and reduced milk production appear to start between a threshold of 1,200 to $1,400 \mu \mathrm{mol} / \mathrm{L}$ of serum BHBA in the first week following calving. Elevations in serum BHBA during the second week postcalving are associated with increased risk of DA and CK, decreased first test milk yield, but greater lactational milk yield.

\section{REFERENCES}

Andersson, L. 1988. Subclinical ketosis in dairy cows. Vet. Clin. North Am. Food Anim. Pract. 4:233-248.

Cameron, R. E. B., P. B. Dyk, T. H. Herdt, J. B. Kaneene, R. Miller, H. F. Bucholtz, J. S. Liesman, M. J. Vandehaar, and R. S. Emery. 1998. Dry cow management, and energy balance as risk factors for displaced abomasum in high producing dairy herds. J. Dairy Sci. 81:132-139.

Correa, M. T., C. R. Curtis, H. N. Erb, J. M. Scarlett, and R. D. Smith. 1990. An ecological analysis of risk factors for postpartum disorders of Holstein-Friesian cows from thirty-two New York farms. J. Dairy Sci. 73:1515-1524.

Curtis, C. R., H. N. Erb, C. J. Sniffen, R. Smith, and D. S. Kronfeld. 1985. Path analysis of dry period nutrition, postpartum metabolic and reproductive disorders, and mastitis in Holstein cows. J. Dairy Sci. 68:2347-2360.

Dohoo, I. R., and S. W. Martin. 1984. Subclinical ketosis: Prevalence and associations with production and disease. Can. J. Comp. Med. 48:1-5.

Duffield, T. F., D. F. Kelton, K. E. Leslie, K. Lissemore, and J. H. Lumsden. 1997. Use of test day milk fat and milk protein to predict subclinical ketosis in Ontario dairy cattle. Can. Vet. J. 38:713-718.

Duffield, T. F., K. E. Leslie, D. Sandals, K. Lissemore, B. W. McBride, J. H. Lumsden, P. Dick, and R. Bagg. 1999. Effect of prepartum administration of a monensin controlled release capsule on cow health and reproduction. J. Dairy Sci. 82:2377-2384.

Duffield, T. F., A. R. Rabiee, and I. J. Lean. 2008a. A meta-analysis of the impact of monensin in lactating dairy cattle. Part 1. Metabolic effects. J. Dairy Sci. 91:1334-1336.

Duffield, T. F., A. R. Rabiee, and I. J. Lean. 2008b. A meta-analysis of the impact of monensin in lactating dairy cattle. Part 3. Health and reproduction. J. Dairy Sci. 91:2328-2341.

Duffield, T. F., D. Sandals, K. E. Leslie, K. Lissemore, B. W. McBride, J. H. Lumsden, P. Dick, and R. Bagg. 1998. Effect of prepartum administration of a monensin controlled release capsule on postpartum energy indicators in lactating dairy cattle. J. Dairy Sci. 81:2354-2361.
Fleischer, P., M. Metzner, M. Beyerbach, M. Hoedemaker, and W. Klee. 2001. The relationship between milk yield and the incidence of some diseases in dairy cows. J. Dairy Sci. 84:2025-2035.

Geishauser, T., K. Leslie, T. Duffield, and V. Edge. 1997. An evaluation of aspartate-aminotransferase activity and $\beta$-hydroxybutyrate concentration in blood as tests for left displaced abomasum in dairy cows. Am. J. Vet. Res. 58:1216-1220.

Grohn, Y. T., S. W. Eicker, and J. A. Hertl. 1995. The association between previous 305-day milk yield and disease in New York state dairy cows. J. Dairy Sci. 78:1693-1702.

Grohn, Y. T., H. N. Erb, C. E. McCulloch, and H. S. Saloniemi. 1989 Epidemiology of metabolic disorders in dairy cattle: Association among host characteristics, disease and production. J. Dairy Sci. 72:1876-1885.

Gustafsson, A. H., L. Andersson, and U. Emanuelson. 1993. Effect of hyperketonemia, feeding frequency and intake of concentrate and energy on milk yield in dairy cows. Anim. Prod. 56:51-60.

Hammon, D. S., I. M. Evjen, T. R. Dhiman, J. P. Goff, and J. L. Walters. 2006. Neutrophil function and energy status in Holstein cows with uterine health disorders. Vet. Immunol. Immunopathol. $113: 21-29$

Herdt, T. H. 2000. Ruminant adaptation to negative energy balance. Vet. Clin. North Am. Food Anim. Pract. 16:215-230.

Huzzey, J. M., D. M. Veira, D. M. Weary, and M. A. G. von Keyserlingk. 2007. Prepartum behaviour and dry matter intake identify dairy cows at risk for metritis. J. Dairy Sci. 90:3220-3233.

Kauppinen, K. 1983. Correlation of whole blood concentrations of acetoacetate, B-hydroxybutyrate, glucose and milk yield. Acta Vet. Scand. 24:337-348.

Kelly, J. M. 1977. Changes in serum B hydroxybutyrate concentrations in dairy cows kept under commercial farm conditions. Vet. Rec. 101:499-502.

Lean, I. J., M. L. Bruss, H. F. Troutt, J. C. Galland, T. B. Farver, J. Rostami, C. A. Holmberg, and L. D. Weaver. 1994. Bovine ketosis and somatotophin: risk factors for ketosis and effects of ketosis on health and production. Res. Vet. Sci. 57:200-209.

LeBlanc, S. J., T. F. Duffield, and K. E. Leslie. 2005. Predictors of abomasal displacement in lactating dairy cows. J. Dairy Sci. $88: 159-170$.

Miettinen, P. V. A., and J. J. Setala. 1993. Relationships between subclinical ketosis, milk production and fertility in Finnish dairy cattle. Prev. Vet. Med. 17:1-8.

Nielen, M., M. G. A. Aarts, G. M. Ad, T. Jonkers, Y. H. Wensing, and Y. H. Schukken. 1994. Evaluation of two cowside tests for the detection of subclinical ketosis in dairy cows. Can. Vet. J. $35: 229-232$.

Osborne, T. M. 2003. An evaluation of metabolic function in transition dairy cows supplemented with Rumensin premix or administered a rumensin controlled-release capsule. MSc dissertation, University of Guelph

Rajala, P. J., and Y. T. Grohn. 1998. Effects of dystocia, retained placenta, and metritis on milk yield in dairy cows. J. Dairy Sci. 81:3172-3181.

SAS Institute. 2004. SAS/STAT Users' Guide, release 9.1. SAS Inst. Inc., Cary, NC.

Shaver, R. 1997. Nutritional risk factors in the etiology of left displaced abomasum in dairy cows: A review. J. Dairy Sci. 80:2449-2453.

Suriyasathaporn, W., C. Heuer, E. N. Noordhuizen-Stassen, and Y. H. Schukken. 2000. Hyperketonemia and udder defense: A review. Vet. Res. 31:397-412.

Van Winden, S. C. L., R. Jorritsma, K. E. Muller, and J. P. T. M. Noordhuizen. 2003. Feed intake, milk yield, and metabolic parameters prior to left displaced abomasums in dairy cows. J. Dairy Sci. 86:1465-1471. 